\title{
Correlation between Biofilm Production and Bacterial Urinary Tract Infections: New Therapeutic Approach
}

\author{
Nanis G. Allam ${ }^{\#}$ \\ Botany Department, Microbiology Section, Faculty of Science, Tanta University, \\ Tanta, Egypt.
}

\begin{abstract}
$\mathrm{B}$ IOFILMS production during bacterial urinary tract infections (UTIs), being responsible for persistence and relapses. Bacterial producing biofilms are difficult to be eradicated as they reveled antibiotics resistant phenotype that correlated to provided protections by biofilms. The present study revealed that the gram negative bacteria (G-ve) were the most common uropathogenic bacteria causing UTIs with $64.28 \%$ biofilm producing ability especially Escherichia coli and Klebsiella pneumoniae. While, gram positive bacteria $(\mathrm{G}+\mathrm{ve})$ represented $23.63 \%$ of UTIs with $57.69 \%$ biofilm producing ability. The isolated uropathogenic bacteria demonstrated a high and widespread resistance $(50 \%$ to $95 \%)$ to all used antibiotics except Nitrofurantoin and Imipenem. The most antibiotics resistant uropathogenic isolates were biofilm producers and some of them revealed haemolytic activity. The present study indicated the importance of studying biofilm producing ability of uropahogenic bacteria as it represented $62.72 \%$ during UTIs. The anti-biofilm activity of cell free supernatant of Lactobacillus plantarum subsp. plantarum DSMZ 20174 and Lactobacillus acidophilus DSMZ 20079T against biofilms of both G-ve and G+ve uropathogenic bacteria beside their acid and bile salt tolerance gave potentiality for their use during UTIs as a beneficial tool for dissociation or prevention of biofilms and enable antimicrobial drugs from eradication of infections.
\end{abstract}

Keywords: Urinary tract infection, Escherichia coli, Antibiotic resistance, Biofilm production

\section{Introduction}

Urinary tract infection (UTI) is one of the most common infection worldwide and causes serious health problem affecting millions of people each year ( Stamm \& Norrby, 2001 and Delcaru et al., 2016). Infections occurring in both males and females of all ages, although women tend to have higher occurrence. Urinary tract infections begin in either the urethra or the kidney and eventually migrate to the urinary tract (Grabe et al., 2013). Most infections are caused by bacteria. The recurrent rate is high and often causes chronic with many infections. Many bacteria causing UTIs are associated with biofilm formation. Bacterial biofilms develop on both living surfaces and artificial implants ( Donlan, 2002).

The majority of UTIs (95\%) resulted from a single bacterial species. $E$. coli is the most frequent infecting bacteria in acute infection (Jellheden et al., 1996 and Ronald, 2002) it is usually found in the lower intestine of humans and present in fecal matter and transferred into the urethra in females. Enterococcus faecalis is another common bacteria inhabiting urinary tract infections, it is similar to E. coli as it inhabits the gastrointestinal tract of humans. Also, this Gram-positive $(\mathrm{G}+\mathrm{ve})$ bacteria are resistance to varieties of antibiotics including penicillin-derivatives, and cephalosporins, this makes its treatment very difficult., Pseudomonas aeruginosa, Klebsiella, Enterococcus spp., and Serratia spp. being most frequently involved in UTIs (Brede \& Shoskes, 2011). G+ve and -ve bacteria have the ability to form biofilms and commonly involved with Enterococcus faecalis, Staphylococcus aureus, Streptococcus viridans, Staphylococcus epidermidis, Escherichia coli, Klebsiella pneumoniae, Proteus mirabilis and Pseudomonas aeruginosa (Donlan, 2001). Biofilm can be defined as a microbiologically derived sessile community characterized with irreversible attach of cells to a substratum or interface and

"Corresponding author affiliation: Tanta University, Faculty of Science, Botany Department, Egypt

Address: Tanta City, El-Gharbia Governorate, Egypt

Phone number: 0403344352 (Work)

E-mail: nallam991@gmail.com,nanisallam@science.tanta.edu.g

DOI : 10.21608/ejm.2017.1014.1021

C2017 National Information and Documentation Center (NIDOC) 
embedded in their produced matrix (Flemming \& Wingender, 2010) of extracellular polymeric substances (polymeric matrix is made from the combination of exopolysaccharides, proteins, enzymes, teichoic acids, and extracellular DNA). The transition from planktonic growth to biofilm cause changes in the surface molecules expression, virulence factors, and metabolic status and enable bacteria to survive during unfavorable conditions (Klebensberger et al., 2009) Biofilm forming bacteria cause a serious problem during UTIs as they involved in up to $80 \%$ of all infections (Stowe et al., 2011). The importance of controlling biofilm producing uropathogeic bacteria is related to protection provided by biofilm. A biofilm develops on the uroepithelium, bacteria enter this biofilm, which protects them from the mechanical flow of urine, host defenses, and antibiotics, making bacterial elimination difficult and become responsible for colonization and persistence (Jacobsen \& Shirtliff, 2011 and Niveditha et al., 2012 ) . Treatment of biofilmassociated uropathogenic bacteria requires new strategies due to the high levels of antibiotic resistance conferred by biofilm structures (biofilm can be up to 1000-fold more resistant to antibiotics than planktonic cells (Lewis, 2010) especially exopolysaccharides in biofilm matrix. The challenge in treatment of uropathogenic biofilm forming bacteria is the antimicrobial resistance shown by biofilms. Probiotics are defined as live microorganisms with health benefit on the host when administered in adequate amounts (Bhan et al., 2005). The use of food based probiotics for nutritional and therapeutic purposes have assumed great significance recently (Das et al., 2013). Lactobacilli gained significant importance in antimicrobial therapy due to their production of different antimicrobial materials such as bacteriocins and biosurfactants (BSs), which affected on formation of biofilms (Gupta \& Garg, 2009). Cell free supernatants of Lactobacillus spp. might control and disperse mature established biofilm of $S$. aureus with matrix degrading enzymes such as deoxyribonucleases, glycosidases and proteases (Kaplan, 2010). The treatment of uropathogenic bacteria with antibiotics is commonly used, but recurrence, persistence and antibiotic resistance have been associated mainly with biofilm producing bacteria. So, the current study aimed to determine the most frequent uropathogenic bacteria and estimated their abilities to produce biofilm and resist antibiotics, consequently find new therapeutic agents able to dissociate formed biofilms and transfer bacterial growth into planktonic mode to facilitate eradication of infection via antimicrobial drugs.

\section{$\underline{\text { Material and Methods }}$}

\section{Sampling}

About 130 urine samples were kindly provided by Tanta University Hospital, Egypt, and private analytic labs in Tanta, Egypt during summer of 2015. The urine samples were collected from persons suffering from UTIs aging 40-60 years, transferred immediately to lab and cultured.

\section{Bacterial colony count in urine samples of UTI} and biochemical identification

Presence of single potential pathogen or two during UTIs could be observed with colony count equal or more than $10^{4} \mathrm{CFU} / \mathrm{ml}$ and interpreted as positive UTIs, a less than $10^{2} \mathrm{CFU} / \mathrm{ml}$ was interpreted as negative UTIs (Schneider \& Riley, 1996). Urine specimens were cultured for isolation of the bacterial agents of UTI on blood agar and MacConky agar media. All the bacteria isolated from urine in this study were identified using Gram reaction, the G-ve isolates were subcultured on MacCkongy, Eosin methylene blue and Cetrimide agar. Gram +ve cocci were cultured on Manitoal salt agar. The bacterial isolates were biochemically identified by the following tests Haemolysin production (Pavlov et al., 2004), Methyl red (MR) (MacFaddin, 1985) and VogesProskauer (VP) (MacFaddin,1980). Also, catalase (Koneman et al., 1992) test was performed to Gram +ve cocci. The identification of Gramnegative, was confirmed by API 20E consists of 27 wells using strip system (BioMereux).

\section{Susceptibility of uropathogenic isolates to different antibiotics}

The antibiotic susceptibility test was conducted according to Kirby Bauer disc diffusion method against the following antibiotics: Oxacillin $(1 \mu \mathrm{g})$, Amoxicillin $(10 \mu \mathrm{g})$, Cephlothin $(30 \mu \mathrm{g})$, Cefuroxime $(30 \mu \mathrm{g})$, Clindamycin $(2 \mu \mathrm{g})$, erythromycin $(15 \mu \mathrm{g})$, Nitrofurantion $(300 \mu \mathrm{g})$, Vancomycin $(30 \mu \mathrm{g})$, Chloramphenicol $(30 \mu \mathrm{g})$ Cefoperazone $(75 \mu \mathrm{g})$, Cefepime $(30 \mu \mathrm{g})$, Imipenem $(10 \mu \mathrm{g})$, Gentamicin $(10 \mu \mathrm{g})$, Rifampin(15 $\mu \mathrm{g})$, Levofloxacin $(5 \mu \mathrm{g})$, ciprofloxacine $(5 \mu \mathrm{g})$, (Sulphamethoxazole/ Trimethoprim) $(25 \mu \mathrm{g})$, and doxycycline $(30 \mu \mathrm{g})$. The entire surface of the Muller Hinton agar plate with $2 \% \mathrm{NaCl}$ was covered with bacterial inoculums, then antibiotics discs were laid 
on the dried surface. The plates were incubated at $35^{\circ} \mathrm{C}$ for $24 \mathrm{~h}$. The diameter of the zone of inhibition was compared according to Clinical and Laboratory Standards Institute guidelines (CLSI, 2010)

\section{Assay of biofilm production \\ Congo red agar medium (CRA)}

The Brain heart infusion agar was supplemented with 5\% sucrose and after sterilization Congo red $(0.08 \mathrm{~g} / \mathrm{l})$ stain which sterilized separately was added to cooled media $\left(55^{\circ} \mathrm{C}\right)$. The CRA was mixed well and distributed into plates (Greenberg et al., 1995). Then plates were inoculated and incubated aerobically for 24 to $48 \mathrm{~h}$ at $37^{\circ} \mathrm{C}$. Presence of black colonies with a dry crystalline revealed that bacteria are biofilm producing and non-producers remain pink (Freeman et al., 1989 and Blanco et al., 2005)

\section{Microtiter plate (MtP) assay}

The test was performed according to Christensen et al. (1982). The Overnight bacterial cultures were diluted 1:10 with Trypticase Soy Broth, 96-well microtiter plates were used and seeded with $200 \mu \mathrm{L}$ per well. The plates were incubated at $37^{\circ} \mathrm{C}$ for $24 \mathrm{~h}$. After four washes in phosphate buffered saline solution $(\mathrm{pH} 7.2)$, biofilms formed by adherent bacteria in plate were fixed with sodium acetate $(2 \%)$ and stained with crystal violet $(0.1 \% \mathrm{w} / \mathrm{v})$. Finally, the microtiter plates were rinsed under running tap water and the dye bound to the walls of the wells was resolubilized with $33 \%$ (v/v) glacial acetic acid. The absorbance or optical density (OD) was measured at $630 \mathrm{~nm}$ using ELISA reader (Hossain \& Uddin, 2014). Control was prepared with crystal violet binding to well exposed only to the culture medium (TSB) without bacteria. OD $<0.120$ considered as negative producers and $>0.240$ considered as biofilm producing bacteria.

\section{Lactobacillus spp.}

Lactobacillus acidophilus DSMZ 20079T and Lactobacillus plantarum subsp. plantarum DSMZ 20174 were kindly provided by bacteriological Lab, Botany Department, Tanta University.

Dissociation of uropathogenic biofilms by cell free supernatants of Lactobacillus spp. using MtP assay

Overnight Lactobacillus cultures contained $10^{7}(\mathrm{CFU} / \mathrm{ml})$ were grown in De Man Rogosa Sharpe ( MRS) broth at $37^{\circ} \mathrm{C}$ for $24 \mathrm{~h}$. Cell free supernatants (CFS) were filter-sterilized (0.22 $\mu \mathrm{m}$ Minisart; Sartorius, Germany) to evaluate their effect on produced biofilm of uropathogenic biofilm producing bacteria using MtP assay. Biofilms were allowed to perform for $24 \mathrm{~h}$ at $37^{\circ} \mathrm{C}$ to allow cell attachment as described before, following the incubation period; media were poured out from wells and washed with sterile phosphate-buffered saline. Cell free supernatant $(200 \mu \mathrm{l} /$ well $)$ were added. The plates were incubated for another $24 \mathrm{~h}$. before the crystal violet staining was performed (Chaieb et al., 2007). Following incubation, biofilm was assessed. Control was prepared with the addition of $(200 \mu \mathrm{l} /$ well $)$ MRS only as a culture medium without bacteria.

\section{Acid and bile tolerance}

MRS broth either with different $\mathrm{pH}$ (2.06.0 adjusted with $\mathrm{HCl}$ ) was prepared (Pereira \& Gibson, 2002) or supplemented with different concentrations of bile salts $(0.1,0.3$ and $0.5 \%$ of ox-bile salts, Oxoid) according to Gilliland et al. (1984), inoculated with $1 \%$ inoculums $\left(1 \times 10^{9} \mathrm{CFU}\right)$ and incubated overnight. Samples were drawn, plated on MRS plates and incubated at $37^{\circ} \mathrm{C}$ for $24 \mathrm{~h}$. Growth on the plates indicated their tolerance to acid or bile salts. The control comprised normal MRS.

\section{Analysis}

SPSS 16 version and Excel 2007 were used to analyze collected data. Results were expressed as mean of three replica \pm stander deviation.

\section{Results and Discussion}

Incidence and classification of bacteria causing UTI

Out of 130 urine samples were investigated, 110 (68 females and 42 males) gave positive cultures with bacterial counts more than 104 $\mathrm{CFU} / \mathrm{ml}$. The gram-negative bacilli $(\mathrm{Gm}-\mathrm{ve})$ isolates represented $76.36 \%$ of isolated bacteria and their biochemical characteristics were illustrated in Table 1 and 2; Echerichia coli gave M R +ve, VP-ve with green metallic sheen on eosin methylene blue agar (presented in 52 of samples and represented $47.27 \%$ of UTI), Klebsiella pneumoniae gave $\mathrm{VP}+\mathrm{ve}$ and MRve (presented in 22 of samples and represented $20 \%$ of UTI), Pseudomonas aureginosa gave MR - ve and VP- ve with green colored colonies on cetrimide agar (presented in 10 of 
samples and represented $9.09 \%$ of UTI). While, gram positive $(\mathrm{Gm}+\mathrm{ve})$ cocci gave yellow color on manitol salt agar with $\beta, \alpha$ haemolysis and represented $23.64 \%$ of isolated bacteria; Staphylococcus aureus gave VP+, MR +ve and catalase +ve (presented in 12 of samples and represented $10.9 \%$ of UTI) and Enterococcus faecalis gave VP+ ve, MR - ve and catalase ve (presented in 14 of samples and represented $12.7 \%$ of UTI). Also, percentage of bacterial UTIs in female was $61.81 \%$ and $38.18 \%$ in male as illustrated in Table 1

TABLE 1. Incidence and classification of bacteria causing urinary tract infections.

\begin{tabular}{lccccc}
\hline $\begin{array}{l}\text { Bacterial } \\
\text { isolates }\end{array}$ & E. coli & K.pneumonia & P.aureginosa & S. aureus & E.faecalis \\
\hline Percentage(\%) & 47.27 & 20 & 9.09 & 10.90 & 12.72 \\
Sex & 32 & 14 & & & \\
femal & 20 & 8 & 7 & 6 & 9 \\
male & + & - & - & 6 & 5 \\
MR & - & + & - & + & - \\
VP & 20 & 12 & - & + & 4 \\
Haemolysis & 22 & - & - & 2 & 6 \\
Non & 10 & 10 & 4 & 5 & 4 \\
$\beta$ & & & 5 & 4 \\
$\alpha$ & & & & & \\
\hline
\end{tabular}

TABLE 2. API 20E biochemical characteristics of Gram-negative bacteria causing urinary tract infections.

\begin{tabular}{|c|c|c|c|}
\hline Identification & Pseudomonas aeruginosa & $\begin{array}{c}\text { Klebsiella } \\
\text { pneumonia }\end{array}$ & $\begin{array}{c}\text { Escherichia } \\
\text { coli }\end{array}$ \\
\hline ONPG & - & + & + \\
\hline $\mathrm{ADH}$ & + & - & - \\
\hline LDC & - & - & - \\
\hline ODC & - & - & - \\
\hline CIT & + & + & - \\
\hline $\mathrm{H} 2 \mathrm{~S}$ & - & - & - \\
\hline URE & - & + & - \\
\hline TDA & - & - & - \\
\hline IND & - & - & + \\
\hline VP & - & + & - \\
\hline GEL & - & - & - \\
\hline GLU & + & + & + \\
\hline MAN & - & + & + \\
\hline INO & - & + & - \\
\hline SOR & - & + & + \\
\hline RHA & - & + & + \\
\hline $\mathrm{SAC}$ & - & + & - \\
\hline MEL & - & + & + \\
\hline AMY & - & + & - \\
\hline ARA & - & + & + \\
\hline OX & + & - & - \\
\hline $\mathrm{NO} 2$ & - & + & + \\
\hline N2 & - & - & - \\
\hline MOB & + & - & + \\
\hline $\mathrm{MC}$ & + & + & + \\
\hline OF-O & + & + & + \\
\hline OF-F & - & + & + \\
\hline
\end{tabular}


The current study revealed that the most common bacteria causing UTIs were G-ve bacilli with percentage $76.36 \%$, the infection was more common in females $(61.81 \%)$ than males. The responsible uropathogenic bacteria for infection were $E$. coli followed by $K$. pneumonia, E. feciales, $S$. aureus and $P$. aeruginosa, the biofilm producing ability of isolated bacteria was $68.45 \%$. In the same connection, Behzadi et al. (2010) found that the G-ve bacteria especially, $E$. coli and K. pneumoniae were the most common uropathogenic bacteria causing UTI.

Antibiotic resistance and biofilm production (CRA) of isolated uropathogenic bacteria

Bacterial biofilms play an important role in UTIs as they responsible for persistent of infections and leading to recurrences and relapses (Delcaru et al., 2016). In addition to antibiotics resistance and biofilms producing abilities, the isolated uropathogenic bacteria revealed hemolytic activity and the highest ratio appeared with isolates of $S$. aureus, E. faecalis and E. coli (83.3, 71.4 and $61.5 \%$, respectively), offering another virulent criteria to them. Johnson (1991) discussed the importance of recognizing virulence factors during UTI which included adhesions, haemolysin, $\mathrm{K}$ capsule, and resistance to serum killing. Also, presence of two virulence factors (haemolysin and biofilm) in combination during UTI, allowing biofilm producing bacteria to be more resistant to therapy (Akhter et al., 2012).

The results as illustrated in Table 3 revealed that $E$. coli which represented the most common uropathogenic bacteria were presented as 7 isolates with different antibiotic resistant patterns (RP) ranging from $50-95 \%$ to all used antibiotics. However, 44.23 of isolated E. coli were non biofilm producer and 55.77 were able to produce biofilm. In the same context, Olorunmola et al. (2013) found that E. coli isolated during UTI demonstrated a high and widespread resistance $(51.1 \%$ to $94.3 \%)$ to all the antibiotics used except Nitrofurantoin. The four different isolates of K. pneumonia according to RP (50-92\%) were able to produce biofilm with $72.72 \%$ and the percentage of biofilm production of two isolates of $P$. aeruginosa was $60 \%$. However, among 4 isolates of $S$. aureus, $75 \%$ were able to produce biofilm and their resistance to antibiotics ranging from $67-92 \%$.

Three isolates of E. faecalis were able to produce biofilm with $42.85 \%$ and their resistance to antibiotics ranging from $50-83 \%$.
TABLE 3. Antibiotic resistance (AR) and biofilm production (CRA) abilities of isolated uropathogenic bacteria.

\begin{tabular}{lcc}
\hline $\begin{array}{l}\text { Bacterial species } \\
\text { (presence frequency } \\
\text { of isolates) }\end{array}$ & $\begin{array}{c}\% \\
\text { Resistance }\end{array}$ & $\begin{array}{c}\text { Biofilm } \\
\text { production }\end{array}$ \\
\hline E. coli $(7)$ & 75 & biofilm \\
E. coli $(3)$ & 83 & biofilm \\
E. coli $(10)$ & 92 & non \\
E. coli $(7)$ & 67 & biofilm \\
E. coli $(9)$ & 95 & biofilm \\
E. coli $(10)$ & 50 & non \\
E. coli $(6)$ & 58 & biofilm \\
K. pneumonia $(4)$ & 75 & biofilm \\
K. pneumonia $(6)$ & 83 & non \\
K. pneumonia $(8)$ & 92 & biofilm \\
K. pneumonia $(4)$ & 50 & biofilm \\
$P$. aureginosa $(6)$ & 82 & biofilm \\
$P$. aureginosa $(4)$ & 77 & non \\
S. aureus $(2)$ & 75 & biofilm \\
S. aureus $(2)$ & 67 & biofilm \\
S. aureus $(5)$ & 92 & biofilm \\
S. aureus $(3)$ & 85 & non \\
E. faecalis $(4)$ & 50 & non \\
E. faecalis $(6)$ & 83 & biofilm \\
E. faecalis $(4)$ & 75 & non \\
\hline
\end{tabular}

The most effective antibiotics against isolated G-ve bacilli were Nitrofurantoin, followed by Imipenem and ciprofloxacin. While, Imipenem followed by Nitrofurantoin were the most effective against $\mathrm{G}+\mathrm{ve}$ cocci. The $\mathrm{G}+\mathrm{ve}$ bacteria were resistant to Cefepime followed by Cephalothin and Erythromycin. While, G-ve bacteria were resistant to Amoxicillin followed by tetracyclin and Trimethoprim/Sulfamethoxazole. Flores-Mireles et al. (2015) found that the high degree of antibiotic resistances was exhibited by all the biofilm producer uropathogenic bacterial isolates compared with non biofilm producer. Nitrofurantoin was found to be a reliable oral drug for treatment of most of the uropathogens (Ahmed et al., 2015).

The obtained results illustrated that, among 5 different species of isolated uropathogenic bacteria, the most antibiotic resistant bacteria were biofilm producer (E. coli with $95 \%$ AR, $K$. pneumonia with $92 \%$ AR, $P$. aeruginosa with $82 \%$ AR, S. aureus with $92 \%$ AR and $E$. faecalis with $83 \%$ AR). So, the most antibiotic resistant biofilm producer isolates were chosen for ingoing experiment.

In-vitro production of biofilm was significantly more frequent among strains causing relapse (Soto et al., 2006). Consequentially, the current study estimated biofilm as a helpful tool to develop a new therapeutic strategy for eradication of persistent 
biofilm-producing uropathogenic bacteria and prevent subsequent relapses. The present study investigated the anti-biofilm ability of cell free supernatant of L. plantarum and L. acidophilus against most antibiotics resistant biofilm producing uropathogenic isolates, the obtained results revealed significant ability of investigated supernatants in dissociation of formed biofilm of both G-ve and +ve uropathogenic isolates. The greatest anti-biofilm activity was recorded against biofilms of $S$. aureus and $E$. coli. The reduction ability of $L$. plantarum and L. acidophilus cell free supernatants was varying from 60.6 to $75 \%$ and 54.54 to $82.14 \%$ against biofilms of investigated bacteria, respectively as illustrated in Table 4. In the same context, Rao et al. (2016) discussed the ability of controlling the pathogenic biofilms using cell free supernatant of Lactobacillus and found that the use of supernatant of L. platarum MYS94 to treat the Klebsiella biofilm resulted in $52.02 \%$ inhibition of biofilm. Similar results of antibiofilm activities were reported by Slama et al. (2013) and Rao et al. (2015) who used supernatant of L. plantarum and L. pentosus in controlling of biofilm production which supported the present work. The anti-biofilm ability of Lactobacillus supernatants could be related to production of inhibitory compounds such as organic acids, bacteriocins or other associated compounds as adopted by Rao et al. (2016). Khiralla et al. (2015) demonstrated the in vitro anti-biofilm effect of cell free supernatants of Lactobacillus sp. against both pathogenic strains of $B$. cereus and $P$. aeruginosa. Also, many researchers reported antibacterial activity of L. plantarum and L. acidophilus which may be attributed to production of bacteriocins (Vuotto et al., 2014 and Shahandashti et al., 2016) and other antimicrobial compounds.

TABLE 4. Absorbance of E. coli biofilm (Mtp) in response to treatment with L. plantarum or L. acidophilus.

\begin{tabular}{lccccc}
\hline $\begin{array}{l}\text { Biofilm } \\
\text { producing } \\
\text { uropathogenic } \\
\text { bacteria }\end{array}$ & control & $\begin{array}{c}\text { L. } \\
\text { plantarum }\end{array}$ & $\begin{array}{c}\text { Percentage } \\
\text { of reduction }\end{array}$ & $\begin{array}{c}\boldsymbol{L} . \\
\text { acidophillus }\end{array}$ & $\begin{array}{c}\text { Percentage } \\
\text { of reduction }\end{array}$ \\
\hline E. coli & $0.45 \pm 0.04$ & $0.15 \pm 0.0^{*}$ & 66.66 & $0.12 \pm 0.0^{*}$ & 73.3 \\
E. coli & $0.31 \pm 0.12$ & $0.09 \pm 0.0^{*}$ & 70.9 & $0.08 \pm 0.0^{*}$ & 74.19 \\
K. pneumonia & $0.33 \pm 0.09$ & $0.13 \pm 0.0^{*}$ & 60.6 & $0.15 \pm 0.0^{*}$ & 54.54 \\
S. aureus & $0.28 \pm 0.01$ & $0.07 \pm 0.0^{*}$ & 75 & $0.05 \pm 0.0^{*}$ & 82.14 \\
\hline
\end{tabular}

All data represented mean of three replica \pm stander deviation, * Significant effect $(\mathrm{P}=0.0001)$ of cell free supernatants of Lactobacillus .spp. on biofilm production of investigated bacteria

The acid and bile tolerance of L. plantarum and L. acidophilus suggested their potential use as therapeutic probiotics during UTI. Bile tolerance is an important criteria during selection of bacteria for probiotic therapeutic uses (Suskovic et al., 2000). It enables the probiotic bacteria to survive, grow and exert its action in the small intestine (Gilliland et al., 1984 and Rao et al., 2015) indicating the tolerance of L. plantarum MYS94 to low $\mathrm{pH}$, which is considered as an important characteristic of probiotic bacteria. The bacterial growth during the present study was increased with increasing $\mathrm{pH}$ values. The growth was recovered at $\mathrm{pH} 4$ and continued to increase with increasing $\mathrm{pH}$ degrees. L. plantarum and L. acidophilus were tolerated to acidity as bacterial growth reduced up to $10 \%$ at $\mathrm{pH} 3$. Also, they tolerated bile salt as the tested levels of salts did not influence growth or survival. There was no difference in cell yield between cultures of control and those with investigated concentrations of bile salt. The present study suggesting the potentiality of using L. plantarum subsp. plantarum DSMZ 20174 and L. acidophilus DSMZ 20079T in controlling biofilm formation during UTIs to transfer uropathogenic bacteria into planktonic mode and manipulated infections regarding to their anti-biofilm ability, antibacterial activity and bile salt and acidity tolerance. 


\section{Conclusion}

Biofilms constitute an important contribution to the high incidence, recurrence, and complications of UTIs, thus requiring efficient prevention and control. So, the current study concerned with studying the incidence of resistance, detection of most frequently uropathogenic bacteria and their biofilm producing abilities to better understanding of the bacterial infection subsequently developing new strategy for prevention and treatment. An ideal choice will include a combination of antibiofilm with effective antibacterial drugs.

\section{Recommendation}

Biofilm estimation may be helpful during UTIs to detect patients who require an effective anti-biofilm like Lactobacillus sp. within their therapeutic strategy to eradicate persistent biofilmforming uropathoenic bacteria, enable antibacterial drugs (as Nitrofurantoin or Imipenem) to be effective and prevent subsequent relapses.

\section{Acknowledgments}

The author expresses here great thanks to staff of the Tanta University Hospital, Egypt, for providing urine samples.

\section{References}

Akhter, J., Anwar, S. and Ahmed, S. (2012) Eterococcal virulence determinants in urinary tract infection patients. Bangladesh Journal of Medical Microbiology, 6(1), 14-17.

Ahmed, N.H., Raghuraman, K., Baruah, F.K. and Grover, R.K.( 2015) Antibiotic resistance pattern of uropathogens: An experience from North Indian cancer patient. Journal of Global Infectious Disease, 7(3), 113-118.

Behzadi, P.E., Behzadi, H., Yazdanbod, R. , Aghapour, Cheshmeh, M.A. and Omran, D.S. (2010) A survey on urinary tract infections associated with the three most common uropathogenic bacteria, Maedica (Buchar), 5(2), 111-115.

Bhan, M.K., Bahl, R. and Bhatnagar, S. (2005) Typhoid and paratyphoid fever. Lancet Journal, 366(9487), 749-762.
Blanco, A.R., Sudano-Roccaro, A., Spoto, G.C., Nostro, A. and Rusciano, D. (2005) Epigallocatechin gallate inhibits biofilm formation by ocular staphylococcal isolates. Antimicrobial Agents Chemotherapy, 49, 4339-4343.

Brede, C.M. and Shoskes, D.A. (2011) The etiology and management of acute prostatitis, Nature Reviews Urology, 8(4), 207-212.

Chaieb, K., Chehab, O., Zmantar, T., Rouabhia, M., Mahdouani, K. and Bakhrouf, A. (2007) In vitro effect of $\mathrm{pH}$ and ethanol on biofilm formation by clinical ica positive Staphylococcus epidermidis strains. Annals of Microbiology, 57, 431-437.

Christensen, G.D., Simpson, W.A., Bisno, A.L. and Beachey, E.H. (1982) Adherence of slime-producing strains of Staphylococcus epidermidis to smooth surfaces. Infection and Immunity, 37, 318-326.

Clinical and Laboratory Standards Institute (CLSI) (2010) "Performance Standards for Antimicrobial Susceptibility Testing: Twentieth Informational Supplement" M100-S20. Wayne, PA, USA.

Das, J.K., Mishra, D., Ray, P., Tripathy, P., Beuria, T.K., Singh, N. and Suar, M. (2013) In vitro evaluation of anti-infective activity of a Lactobacillus plantarum strain against Salmonella enterica serovar Enteritidis. Gut Pathogens, 5, 1-11.

Delcaru, C.I., Alexandru, P., Podgoreanu, M., Grosu, E. Stavropoulos, M., Chifiriuc, C. and Lazar,V. (2016) Microbial biofilms in urinary tract infections and prostatitis: etiology, pathogenicity, and combating strategies. Pathogens, 5 (65), 1-12.

Donlan, R.M. (2001) Biofilms and device-associated infections. Emergent Infectious Disease, 7(2), 277-81.

Donlan, R.M. (2002) Biofilms: microbial life on surfaces. Emergent Infectious Disease, 8, 881-890.

Flemming, H.-C. and Wingender, J. (2010) The biofilm matrix, Nature Reviews Microbiology, 8( 9),623-633.

Flores-Mireles, A.L., Walker, J.N., Caparon, M. and Hultgren, S.J. (2015 ) Urinary tract infections: epidemiology, mechanisms of infection and treatment options, Natural Review of Microbiology, 13(5), 269-284.

Freeman, J., Falkiner, F.R. and Keane, C.T.( 1989) 
New method for detecting slime production by coagulase negative Staphylococci. Journal of Clinical Pathology,42,872-874.

Gilliland, S.E., Staley, T.E. and Bush, L. J. (1984) Importance of bile tolerance of Lactobacillus acidophilus used as dietary adjunct. J Dairy Sci. 67, 3045-3051.

Grabe, M., Bjerklund-Johansen, T.E. and Botto, H. (2013) "Guidelines on Urological Infectious", European Association Of Urology.

Greenberg, J., Simon, L., Harmon-Jones, E., Solomon, S., Pyszczynski, T. and Lyon, D. (1995) Explanations for mortality salience effects: Terror management, value accessibility, or worrisome thoughts? European Journal of Social Psychology, 25, 417-433.

Gupta, V. and Garg, R.( 2009) Probiotics. Indian Journal of Medical Microbiology, 27 (3), 202-209

Hossain, T. and Uddin, K. (2014) Optimization of culture conditions for a biofilm forming bacterium. International Journal of Pharmacy and Biological Sciences, 1, 11-20.

Jacobsen, S.M. and Shirtliff, M.E. (2011) Proteus mirabilis biofilms and catheter-associated urinary tract infections. Virulence, 2, 460-465.

Jellheden, B., Norrby, R.S. and Sandberg, T. (1996) Symptomatic urinary tract infection in women in primary health care: bacteriological, clinical and diagnostic aspects in relation to host response to infection. Scandinavian Journal of Primary Health Care, 14, 122-130.

Johnson, J.R. (1991) Virulence factors in Escherichia coli urinary tract infection. Clinical Microbiology Reviews, 4(1), 80-128.

Kaplan, J.B. (2010) Biofilm dispersal: mechanisms, clinical implications, and potential therapeutic uses. Journal of Dental Research, 89, 205-218.

Khiralla, G. M., Mohamed, E. A. H., Farag, A.G. and Elhariry, H. (2015) Antibiofilm effect of Lactobacillus pentosus and Lactobacillus plantarum cell-free supernatants against some bacterial pathogens. Journal of Biotech Research, 6, 86-95.

Klebensberger, J., Birkenmaier, A., Geffers, R. Kjelleberg, S. and Philipp, B. (2009) Sia A and Sia
$\mathrm{D}$ are essential for inducing autoaggregation as a specific response to detergent stress in Pseudomonas aeruginosa. Environmental Microbiology, 11( 12), 3073-3086.

Koneman, E.W., Allen, S.D., Janda, W.M., Scheckenberger, P.C. and Winn, W.C. (1992) "Color Atlas and Text Book of Diagnostic Microbiology". Philadelphia: J. B. Lippincott Company.

Lewis, K. (2010) Persister cells. Annual Review of Microbiol. 64, 357-372.

MacFaddin, J.F. (1985) "Media for Isolation, Cultivation, Identification, Maintenance of Bacteria", Vol. I . Williams \& Wilkins, Baltimore, MD. MR.

MacFaddin, J. F. (1980) "Biochemical Tests for Identification of Medical Bacteria", $2^{\text {nd }}$ ed. Williams and Wilkins, Baltimore.

Niveditha, S., Pramodhini, S., Umadevi, S., Kumar, S. and Stephen, S. (2012) The isolation and the biofilm formation of uropathogens in the patients with catheter associated urinary tract infections (UTIs). Journal of Clinical and Diagnostic Research, 6,1478-1482.

Olorunmola, F.O., Kolawole, D.O. and Lamikanra, A. (2013) Antibiotic resistance and virulence properties in Escherichia coli strains from cases of urinary tract infections, African J. Infectious Disease, 7(1), 1-7.

Pavlov, A.R., Pavlova, N.V., Kozyavkin, S.A. and Slesarev, A.I. (2004) Recent developments in the optimization of thermostable DNA polymerases for efficient applications. Trends in Biotechnology, 22, 253-260.

Pereira, D.I.A. and Gibson, G.R. (2002) Cholesterol assimilation by lactic acid bacteria and Bifidobacteria isolated from the human gut. Applied and Environmental Microbiology, 68 (9), 4689-4693.

Rao, K.P., Chennappa, G., Suraj, U., Nagaraja, H, Charith Raj, A.P. and Sreenivasa, M.Y. (2015) Probiotic potential of Lactobacillus strains isolated from sorghum-based traditional fermented food. Probiotics and Antimicrobial Proteins, 7,146-156.

Rao, P.K., Hemanth Kumar, N.K. and Sreenivasa, M.Y. (2016) Therapeutic potential of probiotic Lactobacillus plantarum MYS94 against Campylobacter jejuni. International Journal of 
Current Microbiology and Applied Sciences, 5(12), 869-883.

Ronald, A. (2002) The etiology of urinary tract infection: Traditional and emerging pathogens. American Journal of Medicine, 113( 1A), 14-23.

Schneider, P.F. and Riley, T.V. (1996) Staphylococcus saprophyticus urinary tract infections: epidemiological data from Western Australia. European Journal of Epidemiology, 12, 51-55.

Shahandashti, R.V., Kermanshahi, R.K. and Ghadam, P. (2016) The inhibitory effect of bacteriocin produced by Lactobacillus acidophilus ATCC 4356 and Lactobacillus plantarum ATCC 8014 on planktonic cells and biofilms of Serratia marcescens. Turkish Journal of Medical Sciences,46, 1188-1196.

Slama, R. B., Kouidhi, B., Zmantar, T., Chaieb, K. and Bakhrouf, A.( 2013) Anti-listerial and anti-biofilm activities of potential probiotic Lactobacillus strains isolated from Tunisian traditional fermented food. Journal of Food Safety, 33 (2013), 8-16.

Soto, S.M., Smithson, A., Horcajada, J. P., Martinez, J. A., Mensa, J. P. and Vila, J. (2006) Implication of biofilm formation in the persistence of urinary tract infection caused by uropathogenic Escherichia coli. Clinical Microbiology and Infection, 12 (10),1034-1036.

Stamm, W.E. and Norrby, S.R. (2001) Urinary tract infections: disease panorama and challenges. Journal of Infectious Disease, 183 (1), 1-4.

Stowe, S.D., Richards, J.J., Tucker, A. Thompson, T. Melander, R.C. and Cavanagh, J. (2011) Antibiofilm compounds derived from marine sponges. Marine Drugs, 9( 10), 2010-2035.

Suskovic, J., Kos, B., Matosic, S. and Besendorfer, V. (2000) The effect of bile salts on survival and morphology of a potential probiotic strain Lactobacillus acidophilus M92. World Journal of Microbiology and Biotechnology, 16(7), 673-678.

Vuotto, C., Longo, F. and Donelli, G. (2014) Probiotics to counteract biofilm associated infections: promising and conflicting data. International Journal of Oral Science, 6, 189-194. 
الارتباط بين العدوى البكتيرية للمسالك البولية و إنتاج البيوفيلم: اتجاه علاجي جديد

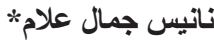

قسم النبات ـ شعبه الميكروبيولوجى ـ ـليه العلوم - جامعه طنطا ـ طنطا - مصر.

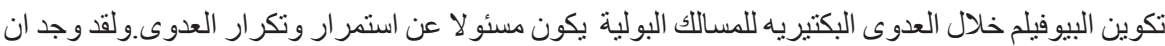

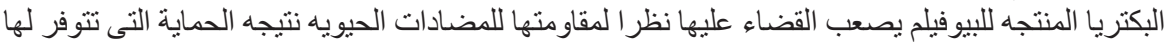

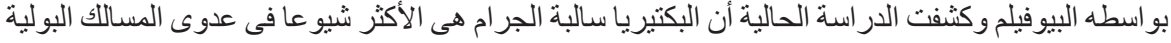

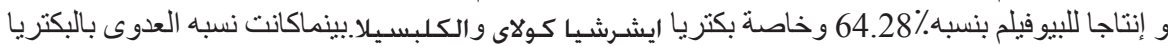

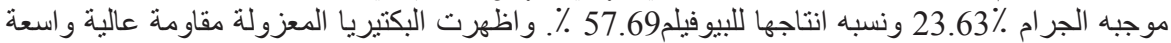

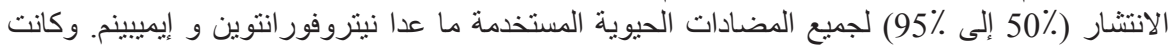

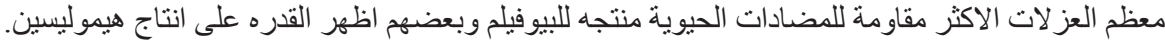

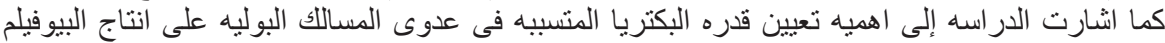

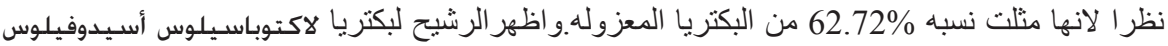

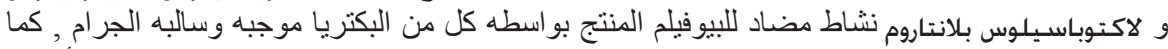

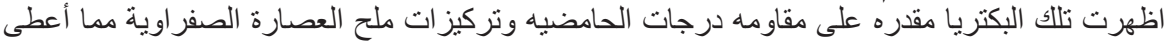

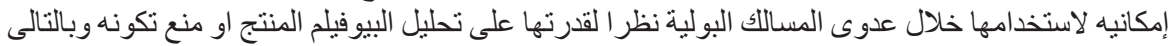
تمكين المضادات الحيويه من القضاء على على العدوى. 